Original article

\title{
Responses of microbial community structure to land-use conversion and fertilization in southern China
}

\author{
Ye Yuan ${ }^{\text {a, b }}$, Xiaoqin Dai a, c, ${ }^{*}$, Ming Xu ${ }^{\text {a, d }}$, Huimin Wang ${ }^{\text {a, c, * }}$, Xiaoli Fu ${ }^{\text {a, c }}$, \\ Fengting Yang ${ }^{\text {a, } c}$ \\ a Qianyanzhou Ecological Research Station, Key Laboratory of Ecosystem Network Observation and Modeling, Institute of Geographic Sciences and Natural \\ Resources Research, Chinese Academy of Sciences, No. 11A, Datun Road, Chaoyang District, Beijing 100101, PR China \\ b University of Chinese Academy of Sciences, Beijing 100049, PR China \\ c Jiangxi Provincial Key Laboratory of Ecosystem Processes and Information, Taihe 343725, PR China \\ d Department of Ecology, Evolution and Natural Resources, Rutgers University, New Brunswick, NJ 08901, USA
}

\section{A R T I C L E I N F O}

\section{Article history:}

Received 14 February 2015

Received in revised form

5 June 2015

Accepted 8 June 2015

Available online 26 June 2015

\section{Keywords:}

Land use

Fertilization

Microbial community structure

Phospholipid fatty acid (PLFA)

Soil physicochemical properties

\begin{abstract}
A B S T R A C T
A short-term experiment was carried out in southern China to investigate the effects of land-use conversion from rice paddies to vegetable fields and fertilization on soil microbial community structure by analyzing soil phospholipid fatty acid (PLFA) profiles. A split-plot design with four replicates was adopted, in which land use (paddy and vegetable field) was the first-level treatment and fertilization (conventional fertilization and no fertilization) was nested as the second level. Our results showed that both land-use conversion and fertilization had significant effects on microbial community structure. After 2 years of land-use conversion, the total amount of PLFAs were 3.54 and $2.97 \mathrm{nmol} \mathrm{g}^{-1}$ for fertilized (V-F) and unfertilized (V-NF) vegetable fields, respectively, and 3.19 and $2.32 \mathrm{nmol} \mathrm{g}^{-1}$ for fertilized (R $-\mathrm{F}$ ) and unfertilized (R-NF) rice paddies, respectively. Soil fungal PLFAs were 1.04 and $0.87 \mathrm{nmol} \mathrm{g}^{-1}$ for $\mathrm{V}-\mathrm{F}$ and $\mathrm{V}-\mathrm{NF}$, respectively, which were significantly increased by 13.9 and 11.4 times compared with those of $\mathrm{R}-\mathrm{F}$ and $\mathrm{R}-\mathrm{NF}$, respectively. The ratio of fungal to bacterial PLFAs significantly increased in vegetable fields compared with rice paddies. No significant differences were found in the total, bacterial, and actinomycetic PLFAs between vegetable fields and rice paddies. The application of fertilizer significantly increased the amount of total PLFAs and bacterial PLFAs. With land-use conversion and fertilization, soil physicochemical properties also changed, and microbial community structure showed a significant relationship with soil water content, $\mathrm{NH}_{4}^{-}-\mathrm{N}$, and $\mathrm{pH}$, which explained the land-use conversion and fertilization effects on soil microbial community composition.
\end{abstract}

(־) 2015 Elsevier Masson SAS. All rights reserved.

\section{Introduction}

Soil microorganisms play a unique role in the processes of nutrient cycling [1], carbon and nitrogen turnover [2,3], and greenhouse gas emissions [4]. Agricultural management practices, such as cropping rotation, irrigation, and fertilization are known to have significant effects on microbial community structure in soils [5-9], which thereby influence the overall agroecosystem functions [10-12]. Land-use conversion, such as the conversion of rice

\footnotetext{
* Corresponding authors. Qianyanzhou Ecological Research Station, Key Laboratory of Ecosystem Network Observation and Modeling, Institute of Geographic Sciences and Natural Resources Research, Chinese Academy of Sciences, No. 11A, Datun Road, Chaoyang District, Beijing 100101, PR China.

E-mail addresses: daixq@igsnrr.ac.cn (X. Dai), wanghm@igsnrr.ac.cn (H. Wang).
}

paddies to uplands or vice versa, can significantly affect soil microbial communities [13,14]. Bossio et al. [15] found that flooded paddy soils had higher abundance of branched fatty acids, lower abundance of monounsaturated fatty acids, and lower abundance of fungi and actinomycetes than upland tomato fields. Sun et al. [16] found that land-use change from paddy to vegetables decreased bacterial diversity and soil microbial biomass despite an increase in the abundance of culturable microorganisms.

Although previous studies have reported that land-use conversion could alter soil microbial communities [17,18], the mechanisms of the effects of land-use conversion on soil microbial communities are poorly understood. It is commonly believed that the land-useconversion-induced changes in soil physical and chemical properties result in the transformation of soil microbial communities, but no consistent relationships have been observed among various 
studies. Soil water content has been shown to influence soil microbial communities directly and indirectly through impacts on soil aeration and nutrient availability [19]. Yang et al. [20] found that total phospholipid fatty acids (PLFAs) decreased significantly after land-use change from paddy to orchard, and soil moisture, organic matter, and nitrogen $(\mathrm{N})$ were found to be the most important environmental factors affecting the variations in microbial community structure. Soil $\mathrm{pH}$ is another important factor that regulates soil microbial communities [21,22]. In the process of land-use conversion from paddy to upland, $\mathrm{pH}$ was one of the most important factors affecting soil microbial community structure [20].

Changes in fertilization often come with land-use change because different crops have different nutrient demands. The application of $\mathrm{N}$ fertilizer has been shown to have a significant influence on soil microbial community [23]. Yevdokimov et al. [24] found that $\mathrm{N}$ addition could increase the ratio of fungal to bacterial biomass and decrease the ratio of Gram-positive to Gramnegative bacteria using the PLFA technique. Li et al. [9] also found that the application of $\mathrm{N}$ fertilizer significantly increased soil microbial biomass, including bacteria, fungi, actinomycetes, Grampositive bacteria, and Gram-negative bacteria. Fertilization can affect soil microbial communities through changing soil physicochemical properties. Fertilization changes the soil $\mathrm{C} / \mathrm{N}$ ratio, which further affects the microbial community and the decomposition rate [25]. Fertilization has been shown to be one of the drivers of soil acidification $[26,27]$ and could affect microbial community structure indirectly by changing soil $\mathrm{pH}$ [28].

In southern China, large areas of rice paddies have been converted to upland vegetable cultivation with the acceleration of urbanization and economic interests in the past decades. The vegetable cultivation area in China has grown from 3.5 to 17.9 million hectares, while the rice cultivation area has decreased from 33.3 to 26.5 million hectares since the 1980s [16]. Understanding the effects of land-use conversion on soil microbial communities is critical to elucidate the mechanisms and processes of greenhouse gas emissions and the potential for greenhouse gas management in China and beyond. And the influence of land-use conversion on soil conditions was undergoing a dynamic change. For example, Sun et al. [16] found that soil microbial community structure differed significantly between paddy and vegetable fields, and the soil microbial community structure of the new vegetable fields (10 years) was significantly different from that of the old vegetable fields (100 years). Thus, short-term, long-term and longer-term studies would give the findings a stronger underpinning. However, few studies have paid attention to the changes of microbial community structure in the early stage of land-use conversion. We hypothesize that two years of land-use conversion from paddy to vegetables and fertilization would significantly alter the soil microbial community structure and soil water content and $\mathrm{pH}$ could be important factors in shaping the soil microbial community structure. The current study used the PLFA method to examine: (1) the effects of land-use conversion from rice paddies to vegetable fields on soil microbial community structure; (2) the effects of fertilization on the soil microbial community structure; and (3) the environmental factors related to the changes in soil microbial community structure.

\section{Materials and methods}

\subsection{Site description}

The experimental fields were located at the Qianyanzhou Ecological Research Station (QYZ, $26^{\circ} 44^{\prime} 46^{\prime \prime} \mathrm{N}, 115^{\circ} 04^{\prime} 05^{\prime \prime} \mathrm{E}$ ) in Jiangxi Province, southern China. The site is a typical, red soil hilly region with a subtropical monsoon climate. According to meteorological observations from 1989 to 2010 at QYZ, the mean air temperature is $18.0{ }^{\circ} \mathrm{C}$ with the coldest and warmest months in January and July, respectively. This area has abundant precipitation with an average annual precipitation of $1509.0 \mathrm{~mm}$. Double cropping of paddy rice is the main cropping system in this area, but large areas of rice paddies have been converted to upland vegetable fields in past decades. Soil texture was sandy loam with $58 \%$ sand, $31 \%$ silt, and $11 \%$ clay. The topsoil $(0-10 \mathrm{~cm})$ has an organic carbon content of $9.40 \mathrm{~g} \mathrm{~kg}^{-1}$ and total $\mathrm{N}$ content of $1.00 \mathrm{~g} \mathrm{~kg}^{-1}$. The soil pH was 4.99 and the bulk density was $1.30 \mathrm{~g} \mathrm{~cm}^{-3}$.

\subsection{Experimental design}

The experimental fields had been continuously cultivating paddy rice for about 10 years. In July 2012, we converted a portion of the rice paddies to upland vegetable fields by draining the fields, with the remaining land continuing with rice cultivation. Each cropping system had two fertilization levels, e.g., conventional fertilization and no fertilization. Thus, the experiment included four treatments with four replicates in a split-plot design, in which the main plots were the cropping systems and each cropping system was split into subplots with and without fertilization. The treatments included vegetable fields with fertilization $(\mathrm{V}-\mathrm{F})$ and without fertilization $(\mathrm{V}-\mathrm{NF})$, and rice fields with fertilization $(\mathrm{R}-\mathrm{F})$ and without fertilization (R-NF). Each plot had an area of $120 \mathrm{~m}^{2}$ $(10 \mathrm{~m} \times 12 \mathrm{~m})$. In rice fields, rice was planted twice a year, with a fallow period in winter. In vegetable fields, vegetables were planted three times a year. The spacing was $17 \mathrm{~cm} \times 25 \mathrm{~cm}$ for rice cultivation and $20 \mathrm{~cm} \times 35 \mathrm{~cm}$ for vegetable cultivation. Compound fertilizer $\left(\mathrm{N}: \mathrm{P}_{2} \mathrm{O}_{5}: \mathrm{K}_{2} \mathrm{O}=15 \%: 15 \%: 15 \%\right)$ and urea were applied at a rate of $358 \mathrm{~kg} \mathrm{~N} \mathrm{ha}^{-1}$ per year to the fertilized fields. The corresponding amount of phosphorus (P) and potassium (K) applied were $63 \mathrm{~kg} \mathrm{P} \mathrm{ha}^{-1}$ and $119 \mathrm{~kg} \mathrm{~K} \mathrm{ha}^{-1}$ per year for paddy fields and $133 \mathrm{~kg} \mathrm{P} \mathrm{ha}^{-1}$ and $254 \mathrm{~kg} \mathrm{~K} \mathrm{ha}^{-1}$ per year for vegetable fields, respectively. Conventional tillage was carried out at the beginning of each growing season.

\subsection{Soil sampling}

Soil samples were collected across the field at a depth of 0-20 cm using a corer device (diameter, $3 \mathrm{~cm}$ ) in July 2014. In each plot, five soil cores were collected and pooled together as a composite sample. Composite samples were taken to the laboratory and plant residues and stones were removed from the soil samples. Each sample was sieved through 2-mm mesh and separated into three parts: one part was air dried for measurements of soil organic carbon (SOC), total $\mathrm{N}(\mathrm{TN})$, and $\mathrm{pH}$, another part was preserved at $-20^{\circ} \mathrm{C}$ as fresh soil for measurements of soil $\mathrm{NH}_{4}^{+}-\mathrm{N}$ and $\mathrm{NO}_{3}^{-}-\mathrm{N}$, and the third part was freeze-dried and preserved at $-80{ }^{\circ} \mathrm{C}$ for determination of PLFAs.

\subsection{Soil property measurements}

Soil water content was automatically recorded by an automatic data logging system through wireless technology. The soil $\mathrm{NH}_{4}^{+}-\mathrm{N}$ and $\mathrm{NO}_{3}^{-}-\mathrm{N}$ were extracted from $20 \mathrm{~g}$ fresh soil with $1 \mathrm{~mol} \mathrm{~L}^{-1} \mathrm{KCL}$ (soil:extract, 1:5) and analyzed using a flow-injection autoanalyzer ((CFA)-AA3, SEAL, Germany). Soil pH was measured at a soil:water ratio of 1:2.5 using a pH meter. SOC and TN were measured using a $\mathrm{C} / \mathrm{N}$ analyzer (Elementar, Vario Max CN, Germany) with the combustion temperature of $900{ }^{\circ} \mathrm{C}$.

\subsection{PLFA analysis}

PLFAs were analyzed using the method described by Bååth and Anderson [29]. Lipids were extracted from freeze-dried soil $(8 \mathrm{~g})$ in 
a single-phase mixture of chloroform:methanol:phosphate buffer (1:2:0.5). After extraction, the lipids were separated into neutral lipids, glycolipids, and polar lipids (phospholipids) on a silicic acid column. The samples were analyzed using a Thermo ISQ gas chromatography-mass spectroscopy system (TRACE GC Ultra ISQ). Helium was used as the carrier gas. The fatty-acid methyl esters extracted by the buffer were then injected in splitless mode and resolved via a DB-5 column $(30 \mathrm{~m} \times 0.25 \mathrm{~mm}$ ID $\times 0.25 \mathrm{~mm})$ using an initial temperature of $150{ }^{\circ} \mathrm{C}$ for $4 \mathrm{~min}$, after which the temperature was ramped to $250{ }^{\circ} \mathrm{C}$ at $4{ }^{\circ} \mathrm{C} \mathrm{min}-1$ and held for $5 \mathrm{~min}$. The concentrations of the individual compounds were obtained by comparing the peaks with an internal standard (nonadecanoic acid methyl ester 19:0). Thirteen PLFAs (i15:0, a15:0, 15:0, i16:0,

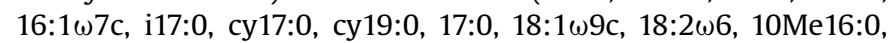
10Me18:0) were used for data analysis. The fatty-acid signatures

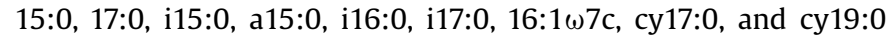
were used as bacterial biomarkers. The fatty acids $18: 1 \omega 9 \mathrm{c}$ and 18:2 $\omega 6$ were used as fungal indicators and 10Me16:0 and 10Me18:0 were used as indicators for the actinomycetes. The fatty acids i15:0, a15:0, i16:0, and i17:0 were used to represent Gram-positive $\left(\mathrm{G}^{+}\right)$ bacteria, while $16: 1 \omega 7 \mathrm{c}$, cy17:0, and cy19:0 were used to represent Gram-negative $\left(\mathrm{G}^{-}\right)$bacteria $[30,31]$.

\subsection{Statistical analysis}

A general linear model for univariate analysis of variance for split plots was used to evaluate the significant differences in soil properties and microbial community structure from the land-use and fertilization treatments $(P<0.05)$. Data shown were means of the four replicates. Principal component analysis (PCA) was used to analyze soil microbial community structure. The relationship between soil microbial community structure and soil properties was analyzed using redundancy analysis (RDA), in which microbial lipids were used as dependent variables and soil properties were explanatory variables [20]. The environmental factors affecting microbial community structure were detected by a permutation test (999 permutations). PCA and RDA were conducted with CANOCO for Windows 4.5. General linear model analysis was performed using SPSS 19.0 (SPSS Inc., Chicago, IL, USA). Figures were generated using the Origin 8.6 package (Origin Lab Corporation, USA) and CANOCO for Windows 4.5 .

\section{Results}

\subsection{Soil physicochemical properties}

Land-use conversion from paddy rice to upland vegetables significantly changed the soil physicochemical properties (Table 1). The concentrations of $\mathrm{NH}_{4}^{+}-\mathrm{N}$ and $\mathrm{NO}_{3}^{-}-\mathrm{N}$ in the vegetable fields increased by 3.6 and 1.2 times, respectively, compared with the concentrations in paddy soils. Soil $\mathrm{pH}$ decreased with the conversion. When fertilizer was applied, soil $\mathrm{pH}$ significantly decreased from 5.00 to 4.56 , and when fertilizer was not applied, the change in soil $\mathrm{pH}$ with land-use conversion was not significant. No significant differences in the SOC and TN concentrations were found between vegetable fields and rice paddies $(P>0.24)$. The land-use conversion significantly decreased the average soil water content of the two years regardless of fertilizer application.

Fertilization significantly influenced soil physicochemical properties (Table 1). Fertilization significantly increased $\mathrm{NH}_{4}^{+}-\mathrm{N}$ and $\mathrm{NO}_{3}^{-}-\mathrm{N}$ by 8.0 and 1.3 times, respectively, compared with the nofertilization treatments. Specifically, $\mathrm{V}-\mathrm{F}$ had significantly higher $\mathrm{NH}_{4}^{-}-\mathrm{N}$ and $\mathrm{NO}_{3}^{-}-\mathrm{N}$ contents than $\mathrm{V}-\mathrm{NF}$, while no significant difference in mineral $\mathrm{N}$ content was found between $\mathrm{R}-\mathrm{F}$ and $\mathrm{R}-\mathrm{NF}$. Land use and fertilization had a significant interactive effect on soil $\mathrm{NH}_{4}^{+}-\mathrm{N}$ and $\mathrm{NO}_{3}^{-}-\mathrm{N}$ content $(P<0.05)$. Fertilization significantly decreased soil $\mathrm{pH}$, especially in upland vegetable fields. Fertilization also significantly increased SOC and TN $(P<0.05)$, but had no interaction with land use type.

\subsection{Soil microbial community}

The microbial biomass represented by total PLFAs was higher in the vegetable soil than in the paddy soil, but the difference was not statistically significant ( $P=0.14$; Table 2). Bacterial PLFAs and actinomycetic PLFAs did not change significantly with land-use conversion $(P>0.12)$. Soil fungal biomass significantly increased with land-use conversion from rice paddies to vegetable fields $(P<0.01)$. Fungal biomass of $\mathrm{V}-\mathrm{F}$ and $\mathrm{V}-\mathrm{NF}$ increased by 13.9 and 11.4 times compared with that of $\mathrm{R}-\mathrm{F}$ and $\mathrm{R}-\mathrm{NF}$, respectively. The fungal/bacterial PLFAs ratio of $\mathrm{V}-\mathrm{F}$ and $\mathrm{V}-\mathrm{NF}$ reached $0.45 \pm 0.04$ and $0.44 \pm 0.08$, respectively, which were significantly higher than those of the paddy soil $(P<0.01)$. Land-use conversion had little impact on the ratio of Gram-negative bacteria to Gram-positive bacteria $\left(\mathrm{G}^{-} / \mathrm{G}^{+} ; P=0.89\right.$; Table 2$)$.

In addition to the land-use conversion effects, we also found that fertilization had considerable impacts on soil microbial community structure (Table 2). Fertilization significantly increased the total PLFAs by $37.5 \%$ in paddy fields and $19.2 \%$ in vegetable fields, especially the bacterial biomass. The soil bacterial biomass of $\mathrm{R}-\mathrm{F}$ was 1.4 times that of $\mathrm{R}-\mathrm{NF}$, and the bacterial biomass of $\mathrm{V}-\mathrm{F}$ was 1.2 times that of $\mathrm{V}-\mathrm{NF}$. Fertilization had little impact on soil fungal biomass $(P=0.36)$, actinomycete biomass $(P=0.61), \mathrm{G}^{-} / \mathrm{G}^{+}$ $(P=0.76)$, and fungal/bacterial ratio $(P=0.998$; Table 2$)$. Land-use conversion and fertilization had no significant interactive effect on soil microbial community composition $(P>0.34$; Table 2$)$.

The effects of land-use conversion and fertilization on soil microbial communities were investigated by principal component analysis (PCA; Fig. 1A). The first and second principal components (PC1 and PC2) explained 56.2 and $36.3 \%$ of the total variance in PLFAs. The effect of land-use conversion was reflected in PC1 with positive values for the vegetable fields (square symbols in Fig. 1A) and negative values for the rice paddies (circular symbols in Fig. 1A), while PC2 carried some information on the effects of

Table 1

Soil physicochemical properties after 2 years of land-use conversion from paddy rice to upland vegetables (Values presented are means \pm SE).

\begin{tabular}{|c|c|c|c|c|c|c|}
\hline & $\mathrm{NH}_{4}^{+}-\mathrm{N} \mathrm{mg} \mathrm{kg}{ }^{-1}$ & $\mathrm{NO}_{3}^{-}-\mathrm{N} \mathrm{mg} \mathrm{kg}{ }^{-1}$ & $\mathrm{pH}$ & SOC $\mathrm{g} \mathrm{kg}^{-1}$ & $\mathrm{TN} \mathrm{g} \mathrm{kg}^{-1}$ & Water content \% \\
\hline $\mathrm{R}-\mathrm{F}$ & $27.88 \pm 8.61^{b}$ & $6.75 \pm 3.10^{\mathrm{b}}$ & $5.00 \pm 0.13^{a}$ & $11.13 \pm 0.45^{\mathrm{ab}}$ & $1.09 \pm 0.03^{\mathrm{ab}}$ & $24.48 \pm 2.33^{\mathrm{a}}$ \\
\hline $\mathrm{R}-\mathrm{NF}$ & $9.39 \pm 1.62^{b}$ & $4.95 \pm 1.72^{\mathrm{b}}$ & $5.21 \pm 0.15^{\mathrm{a}}$ & $10.27 \pm 0.47^{\mathrm{b}}$ & $1.14 \pm 0.03^{b}$ & $24.48 \pm 2.32^{\mathrm{a}}$ \\
\hline $\mathrm{V}-\mathrm{F}$ & $160.68 \pm 14.80^{\mathrm{a}}$ & $19.07 \pm 1.99^{a}$ & $4.56 \pm 0.08^{b}$ & $11.92 \pm 0.57^{\mathrm{a}}$ & $1.21 \pm 0.06^{\mathrm{a}}$ & $18.05 \pm 1.00^{\mathrm{b}}$ \\
\hline $\mathrm{V}-\mathrm{NF}$ & $11.56 \pm 3.98^{\mathrm{b}}$ & $6.16 \pm 1.62^{\mathrm{b}}$ & $4.94 \pm 0.06^{\mathrm{a}}$ & $10.56 \pm 0.18^{\mathrm{ab}}$ & $1.04 \pm 0.05^{\mathrm{b}}$ & $17.68 \pm 0.97^{\mathrm{b}}$ \\
\hline Land-use (L) & $P<0.01$ & $P<0.01$ & $P<0.01$ & $P=0.25$ & $P=0.24$ & $P<0.01$ \\
\hline Fertilization (F) & $P<0.01$ & $P<0.01$ & $P=0.02$ & $P=0.03$ & $P=0.03$ & $P=0.92$ \\
\hline $\mathrm{L} \times \mathrm{F}$ & $P<0.01$ & $P=0.03$ & $P=0.45$ & $P=0.59$ & $P=0.22$ & $P=0.92$ \\
\hline
\end{tabular}

Data labeled with different letters indicated soil properties were significantly different at $P<0.05$.

Treatments: R-F: rice paddies with fertilization; R-NF: rice paddies with no fertilization; V-F: vegetables with fertilization; V-NF: vegetables without fertilization. Variables: $\mathrm{NH}_{4}^{+}-\mathrm{N}$ : ammonium nitrogen; $\mathrm{NO}_{3}^{-}-\mathrm{N}$ : nitrate nitrogen; SOC: soil organic carbon; TN: total nitrogen. 
Table 2

Soil microbial community structure after 2 years of land-use conversion from paddy rice to upland vegetables (Values presented are means \pm SE).

\begin{tabular}{|c|c|c|c|c|c|c|}
\hline Source of variation & Total PLFAs nmol $\mathrm{g}^{-1}$ & Bacterial PLFAs nmol g ${ }^{-1}$ & Fungal PLFAs nmol $\mathrm{g}^{-1}$ & Actinomycetic PLFAs nmol g ${ }^{-1}$ & $\mathrm{G}^{-}$PLFAs $/ \mathrm{G}^{+}$PLFAs & Fungal/bacterial PLFAs \\
\hline $\mathrm{R}-\mathrm{F}$ & $3.19 \pm 0.13^{\mathrm{ab}}$ & $3.09 \pm 0.13^{a}$ & $0.07 \pm 0.01^{\mathrm{b}}$ & $0.03 \pm 0.01^{\mathrm{a}}$ & $0.71 \pm 0.21^{\mathrm{a}}$ & $0.02 \pm 0.00^{\mathrm{a}}$ \\
\hline $\mathrm{R}-\mathrm{NF}$ & $2.32 \pm 0.14^{\mathrm{b}}$ & $2.22 \pm 0.14^{\mathrm{b}}$ & $0.07 \pm 0.00^{\mathrm{b}}$ & $0.02 \pm 0.01^{\mathrm{a}}$ & $0.81 \pm 0.19^{a}$ & $0.03 \pm 0.00^{\mathrm{a}}$ \\
\hline $\mathrm{V}-\mathrm{F}$ & $3.54 \pm 0.56^{\mathrm{a}}$ & $2.41 \pm 0.44^{\mathrm{ab}}$ & $1.04 \pm 0.14^{\mathrm{a}}$ & $0.09 \pm 0.04^{\mathrm{a}}$ & $0.73 \pm 0.24^{\mathrm{a}}$ & $0.45 \pm 0.04^{\mathrm{b}}$ \\
\hline $\mathrm{V}-\mathrm{NF}$ & $2.97 \pm 0.23^{\mathrm{ab}}$ & $2.04 \pm 0.18^{\mathrm{b}}$ & $0.87 \pm 0.11^{\mathrm{a}}$ & $0.06 \pm 0.05^{a}$ & $0.74 \pm 0.10^{\mathrm{a}}$ & $0.44 \pm 0.08^{b}$ \\
\hline Land-use (L) & $P=0.14$ & $P=0.12$ & $P<0.01$ & $P=0.14$ & $P=0.89$ & $P<0.01$ \\
\hline Fertilization (F) & $P=0.04$ & $P=0.03$ & $P=0.36$ & $P=0.61$ & $P=0.76$ & $P=0.998$ \\
\hline $\mathrm{L} \times \mathrm{F}$ & $P=0.64$ & $P=0.35$ & $P=0.34$ & $P=0.73$ & $P=0.81$ & $P=0.81$ \\
\hline
\end{tabular}

Data labeled with different letters indicated soil microbial community structure were significantly different at $P<0.05$.

Treatments: R-F: rice paddies with fertilization; R-NF: rice paddies with no fertilization; V-F: vegetables with fertilization; V-NF: vegetables without fertilization.
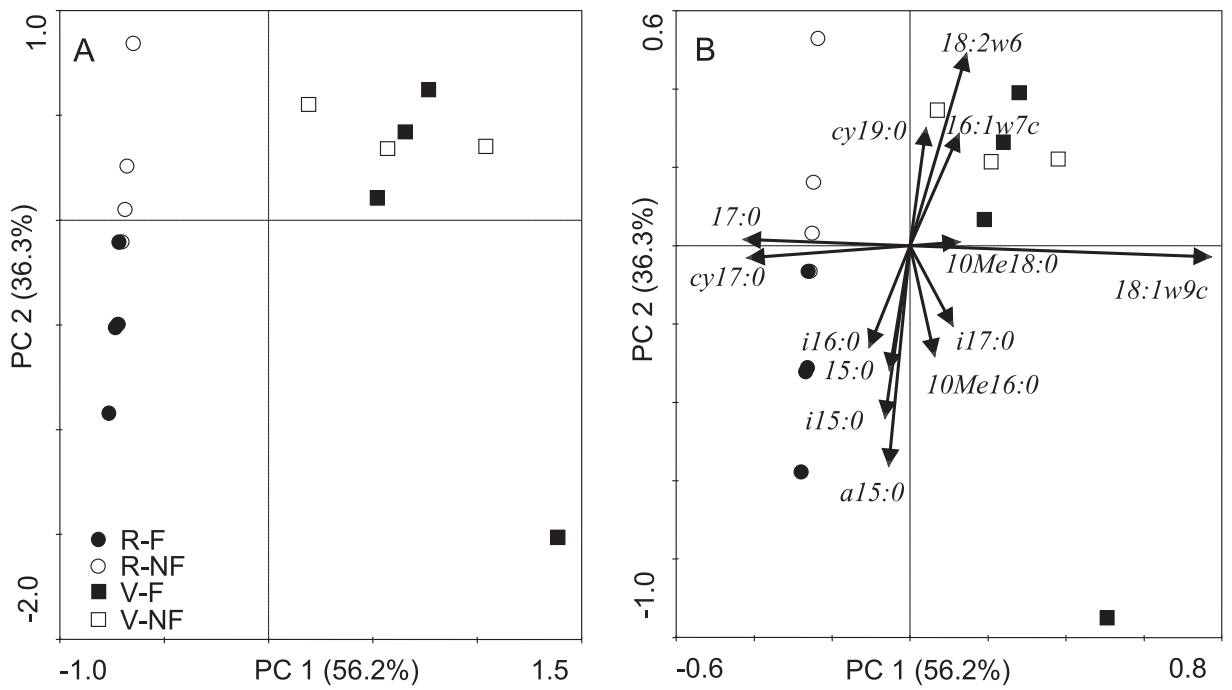

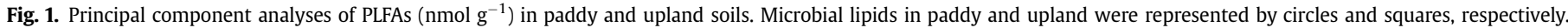

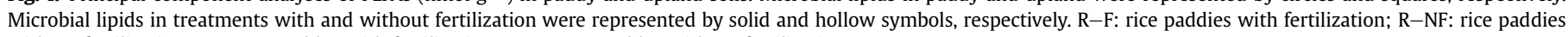
with no fertilization; V-F: vegetables with fertilization; V-NF: vegetables without fertilization.

fertilization (filled versus open symbols in Fig. 1A) on microbial communities. Specifically, the vegetable soil was more abundant in $18: 1 w 9 c$, while the paddy soil was more abundant in 17:0 and cy17:0 (Fig. 1B). As indicated by PC2, fertilization favored the a15:0 and i15:0 PLFAs, while the non-fertilized soils favored 18:2w6 (Fig. 1B).

\subsection{Relationships of microbial community structure with soil properties}

Soil microbial community structure was significantly influenced by changes in environmental factors associated with land-use conversion and fertilization. Redundancy analysis (RDA) showed that the first (RD1) and second axes (RD2) explained 54.5 and 8.1\% of the total variance in the PLFA profiles, respectively (Fig. 2). Soil water content, $\mathrm{NH}_{4}^{+}-\mathrm{N}$, and $\mathrm{pH}$ were the key factors in shaping the soil microbial communities (Fig. 2). This was also demonstrated by simple linear regression analysis, which showed that soil water content, $\mathrm{NH}_{4}^{+}-\mathrm{N}$, and $\mathrm{pH}$ explained 51.6, 22.4, and 19.6\%, respectively, of the variance in soil microbial community structure (Table 3).

\section{Discussion}

\subsection{Effect of land-use conversion on microbial community structure}

In this study, we found that land-use conversion from rice paddies to vegetable fields significantly altered the fungal PLFAs

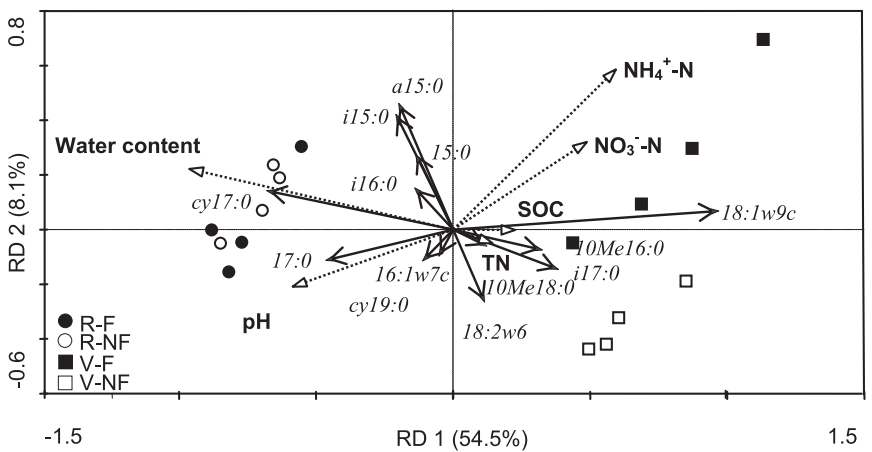

Fig. 2. Redundancy analyses of the soil microbial community structure ( $\mathrm{nmol} \mathrm{g}^{-1}$ ). Microbial lipids in paddy and upland were represented by circles and squares, respectively. Microbial lipids in treatments with and without fertilization were represented by solid and hollow symbols, respectively. The solid lines represent the lipid signatures and the dotted lines represent the environmental variables. $\mathrm{R}-\mathrm{F}$ : rice paddies with fertilization; $\mathrm{R}-\mathrm{NF}$ : rice paddies with no fertilization; $\mathrm{V}-\mathrm{F}$ : vegetables with fertilization; $\mathrm{V}-\mathrm{NF}$ : vegetables without fertilization. $\mathrm{NH}_{4}^{+}-\mathrm{N}$ : ammonium nitrogen; $\mathrm{NO}_{3}^{-}-\mathrm{N}$ : nitrate nitrogen; SOC: soil organic carbon; $\mathrm{TN}$ : total nitrogen.

and the fungal/bacterial PLFA ratio (Fig. 1, Table 2). Further analyses showed that the effect of land-use conversion on soil microbial communities mainly resulted from its impacts on environmental factors, such as soil water content, $\mathrm{NH}_{4}^{+}-\mathrm{N}$, and soil $\mathrm{pH}$. After the land-use conversion, the soil environment turned from anaerobic to aerobic, and the abundance of PLFA cy17:0, which is indicative of 
Table 3

Results of the simple linear regression analysis between soil physicochemical properties and microbial community structure.

\begin{tabular}{llrr}
\hline & $\mathrm{R}^{2}$ & $\mathrm{P}$ & $\mathrm{F}$ \\
\hline Water content & $0.52^{* *}$ & $<0.01$ & 14.91 \\
$\mathrm{NH}_{4}^{+}-\mathrm{N}$ & $0.22^{*}$ & 0.02 & 4.05 \\
$\mathrm{pH}$ & $0.20^{*}$ & 0.03 & 3.41 \\
$\mathrm{NO}_{3}^{-}-\mathrm{N}$ & 0.14 & 0.10 & 2.34 \\
$\mathrm{SOC}$ & 0.03 & 0.64 & 0.49 \\
$\mathrm{TN}$ & 0.02 & 0.67 & 0.49 \\
\hline
\end{tabular}

*Significant at $P<0.05,{ }^{* *}$ significant at $P<0.01$.

Variables: $\mathrm{NH}_{4}^{+}-\mathrm{N}$ : ammonium nitrogen; $\mathrm{NO}_{3}^{-}-\mathrm{N}$ : nitrate nitrogen; SOC: soil organic carbon; TN: total nitrogen.

anaerobic bacteria [32], decreased significantly. Meanwhile, the abundance of a fungal biomarker, 18:1 1 9c, significantly increased, suggesting the converted vegetable fields favored fungal growth. Indeed, we found that the fungal biomass and the ratio of fungi/ bacteria dramatically increased with the land-use conversion from rice paddies to vegetable fields (Table 2). Our results were in line with previous studies [15,20]. For example, Yang and Zhang [20] found that land-use conversion from paddy to orchard significantly increased the relative abundance of fungi. In an incubation experiment using polycarbonate pots, Tian et al. [33] found that the fungi/bacteria ratio of the continuously flooded treatment was 1.4 times lower than the non-flooded treatment, which supports our result that water regimes could alter the fungi/bacteria ratio. It was noted that the higher ratio of fungi/bacteria might indicate better sustainability of the vegetable fields, because fungi have greater growth yield efficiency than bacteria. That is, for each unit of substrate $C$ used, fungi invest a greater proportion into biomass and metabolite production than bacteria [34]. Thus, fungi-dominated soils might have greater C storage and slower C turnover [34]. De Vries et al. [35] found that fungi-dominated soil might result in lower $\mathrm{N}$ mineralization as fungi have higher $\mathrm{C} / \mathrm{N}$ ratios than bacteria. However, our result that the land-use conversion had little effect on bacterial biomass does not support other studies in the literature. For example, Li et al. [13] found that soil bacterial biomass significantly decreased 5 years after land-use conversion from paddy to vegetable field in Jiangsu Province.

In this study, we found that the most significant factor affecting the structure of soil microbial communities was soil water content (Fig. 2, Table 3), which was significantly decreased by the conversion from paddy to vegetables (Table 1). Previous studies also concluded that soil water content was one of the major determinants of soil microbial community composition [19]. Landuse-conversion-induced changes in soil microbial community were also related to soil $\mathrm{pH}$ and $\mathrm{NH}_{4}^{+}-\mathrm{N}$ content. A previous study also concluded that soil $\mathrm{pH}$ and nutrient status, not specifically land-use type, could best predict shifts in microbial community composition [21]. We found that soil $\mathrm{pH}$ significantly decreased after 2 years of conversion from the rice paddies to vegetable fields. Our result was similar to a previous study where $\mathrm{pH}$ decreased after conversion to upland from paddy fields in acidic soil [36]. This decreased soil $\mathrm{pH}$ might play an important role in shaping the soil microbial community under land-use conversion. Rousk et al. [37] found that bacterial growth decreased and fungal growth increased with lower $\mathrm{pH}$.

\subsection{Effect of fertilization on microbial community structure}

Soil microbial community structure was influenced by fertilization. In our study, fertilization exerted a significant impact on the bacterial biomass (Table 2 ), which agrees with a previous study that the effect of fertilizer amendment on bacterial communities was more dramatic than land use change [6]. The total PLFAs in this study increased with $\mathrm{N}$ fertilization, which was consistent with previous studies [9]. Most soil microbes are heterotrophic and use organic $C$ as $C$ and energy sources. Therefore, fertilization could not only stimulate microbial growth by providing a $\mathrm{N}$ source but also promote plant growth, providing root exudates as $\mathrm{C}$ sources for microbial growth $[9,38,39]$.

In this study we found that fertilization significantly increased soil $\mathrm{NH}_{4}^{+}-\mathrm{N}, \mathrm{NO}_{3}^{-}-\mathrm{N}, \mathrm{SOC}$, and $\mathrm{TN}$, and decreased soil $\mathrm{pH}$ (Table 1 ). Liebig et al. [40] also found that fertilization decreased soil $\mathrm{pH}$ and increased SOC and TN. Soil acidification through nitrification of ammoniacal fertilizer was responsible for the $\mathrm{pH}$ decrease, which further altered the soil microbial community composition. Earlier studies also found that soil total PLFAs were highly correlated with SOC and TN [41]. In this study, fertilization increased SOC and TN as well as total PLFAs, although SOC and TN had no significant effect on soil microbial community structure.

\section{Conclusions}

After land-use conversion from paddy to vegetable fields, fungal PLFAs and the fungal/bacterial ratio significantly increased. Bacterial PLFAs did not change significantly. Similarly, fertilization enhanced the total PLFAs and bacterial PLFAs in both rice paddies and vegetable fields. Land use and fertilization had no interactive effect on soil microbial community composition. Soil microbial community structure was affected by soil physicochemical properties, which were subject to land-use conversion and fertilization. Soil water content, $\mathrm{NH}_{4}^{+}-\mathrm{N}$, and $\mathrm{pH}$ were the three most important factors in shaping the soil microbial community structure. These findings contribute towards an understanding of the changes in soil microbial communities in response to agricultural management practices and land-use conversion trends in China and beyond.

\section{Acknowledgments}

This work was financially supported by the National Basic Research Program of China (973 Program, 2012CB417103) and the National Natural Science Foundation of China (41001179). Authors also thank the academic editor and anonymous reviewers for their constructive comments, which helped in improving the manuscript.

\section{References}

[1] D.J. Moriarty, The role of microorganisms in aquaculture ponds, Aquaculture 151 (1997) 333-349.

[2] D.R. Nemergut, A.R. Townsend, S.R. Sattin, K.R. Freeman, N. Fierer, J.C. Neff, W.D. Bowman, C.W. Schadt, M.N. Weintraub, S.K. Schmidt, The effects of chronic nitrogen fertilization on alpine tundra soil microbial communities: implications for carbon and nitrogen cycling, Environ. Microbiol. 10 (2008) 3093-3105.

[3] J.P. Schimel, S.M. Schaeffer, Microbial control over carbon cycling in soil, Front. Microbiol. 3 (2012).

[4] P. Smith, D. Martino, Z. Cai, D. Gwary, H. Janzen, P. Kumar, B. McCarl, S. Ogle, F. O'Mara, C. Rice, Greenhouse gas mitigation in agriculture, Philosophical Trans. R. Soc. B: Biological Sci. 363 (2008) 789-813.

[5] C. Crecchio, A. Gelsomino, R. Ambrosoli, J.L. Minati, P. Ruggiero, Functional and molecular responses of soil microbial communities under differing soil management practices, Soil Biol. Biochem. 36 (2004) 1873-1883.

[6] K. Jangid, M.A. Williams, A.J. Franzluebbers, J.S. Sanderlin, J.H. Reeves, M.B. Jenkins, D.M. Endale, D.C. Coleman, W.B. Whitman, Relative impacts of land-use, management intensity and fertilization upon soil microbial community structure in agricultural systems, Soil Biol. Biochem. 40 (2008) 2843-2853.

[7] H. Chu, X. Lin, T. Fujii, S. Morimoto, K. Yagi, J. Hu, J. Zhang, Soil microbial biomass, dehydrogenase activity, bacterial community structure in response to long-term fertilizer management, Soil Biol. Biochem. 39 (2007) 2971-2976.

[8] N. Fierer, J. Schimel, P. Holden, Influence of drying-rewetting frequency on soil bacterial community structure, Microb. Ecol. 45 (2003) 63-71.

[9] Y.J. Li, X. Chen, I.H. Shamsi, P. Fang, X.Y. Lin, Effects of irrigation patterns and 
nitrogen fertilization on rice yield and microbial community structure in paddy soil, Pedosphere 22 (2012) 661-672.

[10] K. Schwärzel, S. Carrick, A. Wahren, K.H. Feger, G. Bodner, G. Buchan, Soil hydraulic properties of recently tilled soil under cropping rotation compared with two-year pasture, Vadose Zone J. 10 (2011) 354-366.

[11] A.D. Halvorson, B.J. Wienhold, A.L. Black, Tillage, nitrogen, and cropping system effects on soil carbon sequestration, Soil Sci. Soc. Am. J. 66 (2002) 906-912.

[12] A. Roldán, J. Salinas-García, M. Alguacil, F. Caravaca, Changes in soil enzyme activity, fertility, aggregation and $\mathrm{C}$ sequestration mediated by conservation tillage practices and water regime in a maize field, Appl. Soil Ecol. 30 (2005) $11-20$.

[13] Z.P. Li, X.C. Wu, B.Y. Chen, Changes in transformation of soil organic C and functional diversity of soil microbial community under different land uses, Agric. Sci. China 6 (2007) 1235-1245.

[14] A. Nakamura, C.C. Tun, S. Asakawa, M. Kimura, Microbial community responsible for the decomposition of rice straw in a paddy field: estimation by phospholipid fatty acid analysis, Biol. Fertil. Soils 38 (2003) 288-295.

[15] D. Bossio, K. Scow, Impacts of carbon and flooding on soil microbial communities: phospholipid fatty acid profiles and substrate utilization patterns, Microb. Ecol. 35 (1998) 265-278.

[16] B. Sun, Z.X. Dong, X.X. Zhang, Y. Li, H. Cao, Z.L. Cui, Rice to vegetables: shortversus long-term impact of land-use change on the indigenous soil microbial community, Microb. Ecol. 62 (2011) 474-485.

[17] J. Lagerlöf, L. Adolfsson, G. Börjesson, K. Ehlers, G.P. Vinyoles, I. Sundh, Landuse intensification and agroforestry in the Kenyan highland: impacts on soil microbial community composition and functional capacity, Appl. Soil Ecol. 82 (2014) 93-99.

[18] R.E. Drenovsky, K.L. Steenwerth, L.E. Jackson, K.M. Scow, Land use and climatic factors structure regional patterns in soil microbial communities 19 (2010) 27-39.

[19] R.E. Drenovsky, D. Vo, K.J. Graham, K.M. Scow, Soil water content and organic carbon availability are major determinants of soil microbial community composition, Microb, Ecol, 48 (2004) 424-430.

[20] D. Yang, M. Zhang, Effects of land-use conversion from paddy field to orchard farm on soil microbial genetic diversity and community structure, Eur. J. Soil Biol. 64 (2014) 30-39.

[21] C.L. Lauber, M.S. Strickland, M.A. Bradford, N. Fierer, The influence of soil properties on the structure of bacterial and fungal communities across landuse types, Soil Biol. Biochem. 40 (2008) 2407-2415.

[22] C.L. Lauber, M. Hamady, R. Knight, N. Fierer, Pyrosequencing-based assessment of soil pH as a predictor of soil bacterial community structure at the continental scale, Appl. Environ. Microbiol. 75 (2009) 5111-5120.

[23] P. Shi, S. Wang, S. Jia, O. Gao, Effect of 25-year fertilization on soil microbial biomass and community structure in a continuous corn cropping system, Arch. Agron. Soil Sci. 61 (9) (2015) 1303-1317.

[24] I. Yevdokimov, A. Gattinger, F. Buegger, M. Schloter, J. Munch, Change in the structure and activity of a soil microbial community caused by inorganic nitrogen fertilization, Microbiology 81 (2012) 743-749.

[25] P. Marschner, E. Kandeler, B. Marschner, Structure and function of the soil microbial community in a long-term fertilizer experiment, Soil Biol. Biochem. 35 (2003) 453-461.

[26] A.S.R. Juo, A. Dabiri, K. Franzluebbers, Acidification of a kaolinitic Alfisol under continuous cropping with nitrogen-fertilization in West-Africa, Plant Soil 171 (1995) 245-253.

[27] J.H. Guo, X.J. Liu, Y. Zhang, J.L. Shen, W.X. Han, W.F. Zhang, P. Christie, K.W. Goulding, P.M. Vitousek, F.S. Zhang, Significant acidification in major Chinese croplands, Science 327 (2010) 1008-1010.

[28] W. Zhong, T. Gu, W. Wang, B. Zhang, X. Lin, O. Huang, W. Shen, The effects of mineral fertilizer and organic manure on soil microbial community and diversity, Plant Soil 326 (2010) 511-522.

[29] E. Båăth, T.H. Anderson, Comparison of soil fungal/bacterial ratios in a pH gradient using physiological and PLFA-based techniques, Soil Biol. Biochem. 35 (2003) 955-963.

[30] Å. Frostegård, E. Bååth, The use of phospholipid fatty acid analysis to estimate bacterial and fungal biomass in soil, Biol. Fertil. Soils 22 (1996) 59-65.

[31] I. Djukic, F. Zehetner, A. Mentler, M.H. Gerzabek, Microbial community composition and activity in different Alpine vegetation zones, Soil Biol. Biochem. 42 (2010) 155-161.

[32] L. Zelles, R. Rackwitz, O., Bai, T. Beck, F. Beese, Discrimination of microbia diversity by fatty acid profiles of phospholipids and lipopolysaccharides in differently cultivated soils, in: The Significance and Regulation of Soil Biodiversity, Springer, 1995, pp. 115-122.

[33] J. Tian, M. Dippold, J. Pausch, E. Blagodatskaya, M. Fan, X. Li, Y. Kuzyakoy, Microbial response to rhizodeposition depending on water regimes in paddy soils, Soil Biol. Biochem. 65 (2013) 195-203.

[34] R.K. Thiet, S.D. Frey, J. Six, Do growth yield efficiencies differ between soil microbial communities differing in fungal: bacterial ratios? Reality check and methodological issues, Soil Biol. Biochem. 38 (2006) 837-844.

[35] F.T. De Vries, E. Hoffland, N. van Eekeren, L. Brussaard, J. Bloem, Fungal/bacterial ratios in grasslands with contrasting nitrogen management, Soil Biol. Biochem. 38 (2006) 2092-2103.

[36] Z. Cao, J. Huang, C. Zhang, A. Li, Soil quality evolution after land use change from paddy soil to vegetable land, Environ. Geochem. Health 26 (2004) 97-103.

[37] J. Rousk, P.C. Brookes, E. Bååth, Fungal and bacterial growth responses to N fertilization and $\mathrm{pH}$ in the 150-year 'Park Grass' UK grassland experiment, FEMS Microbiol. Ecol. 76 (2011) 89-99.

[38] W. Zhong, Z. Cai, Long-term effects of inorganic fertilizers on microbia biomass and community functional diversity in a paddy soil derived from quaternary red clay, Appl. Soil Ecol. 36 (2007) 84-91.

[39] Y. Lu, A. Watanabe, M. Kimura, Contribution of plant-derived carbon to soil microbial biomass dynamics in a paddy rice microcosm, Biol. Fertil. Soils 36 (2002) 136-142.

[40] M. Liebig, G.E. Varvel, J.W. Doran, B.J. Wienhold, Crop sequence and nitrogen fertilization effects on soil properties in the western corn belt, Soil Sci. Soc. Am. J. 66 (2002) 596-601.

[41] R. Wagai, K. Kitayama, T. Satomura, R. Fujinuma, T. Balser, Interactive influences of climate and parent material on soil microbial community structure in Bornean tropical forest ecosystems, Ecol. Res. 26 (2011) 627-636. 